\title{
Pressure mounts to resume chemical weapons production
}

REPORTS of the use of poison gas by Soviet troops in Afghanistan are being used to help generate support for allowing the US military to resume the production of chemical weapons banned since the late 1960s.

Supporters of such a move argue that there is considerable evidence that the Soviet Union already possesses a chemical warfare capability considerably superior to that of the US - and that the reports from Afghanistan indicates its willingness to use it.

Critics, however, argue that many widely-quoted estimates of the Soviet stockpile of chemical weapons are greatly exaggerated, and point out that there is as yet no confirmed evidence that Soviet troops have used anything more than riot control agents against Afghan forces.

The US army has been pushing for several years to proceed with production facilities for a new generation of so-called binary weapons, in which two non-lethal gases combine on firing or impact to form a deadly mixture. Such weapons have been under research since the mid-1960s.

Congress rejected this proposal in both 1974 and 1975. More recently, plans for $\$ 111$ million production facility was cut by the White House from the Defense Department proposed budget for the fiscal year 1981, currently before Congress.

But pressure is building for the proposal to be reinstated. And at the same time, the Pentagon is increasing the scope of the plans that it would like to put into effect. In January, Defense Secretary Harold Brown announced that, whereas previously it had been intended only to produce projectiles containing the two gases, plans are now being drawn up for producing binary bombs and warheads as well.

Last week the possibility of moving to production came even closer when William Perry, Defense Under Secretary for research and engineering, signed a memorandum instructing the department to complete designs for such a facility and draw up a construction schedule.

How sympathetic Congress is likely to be towards a request for funds for this purpose remains unclear. But a considerable number of articles have appeared in the US press in recent weeks focusing both on the claims about the use of poison gas in Afghanistan (which even the Central Intelligence Agency, after careful study, is said to have been unable to confirm), and more broadly on the apparent inferiority of the US's chemical weapons capability.

An article in Time, for example, states that "without a credible chemical counterpunch, it becomes more likely that the US would have to resort to tactical nuclear weapons as a response to a Soviet attack"'.

Dr Matthew Meselson, professor of biology at Harvard University and a longtime opponent of chemical and biological warfare, claims that many of the current estimates - such as one that the USSR has a stockpile of 350,000 tons of chemical weapons, compared to only 42,000 tons in the US - are unrealistic and based on faulty speculation, even according to some Defense Department calculations.

"I am concerned that making policy by excitability is likely to lock us into a series of policies which are unwise from a defence point of view, since I do not think that chemical weapons are that useful in combat situations", Dr Meselson said last week.

The pressure to reintroduce chemical weapons production has coincided with the latest round of chemical disarmament talks between the US and the USSR in Geneva. At the end of the last round in August 1979 , US officials expressed optimism that real progress towards an agreement banning such weapons was beginning to be made.

Some now argue that, if the US steps up its production, this will provide added pressure for an agreement. Others, however, argue that it could create a new stumbling block to the negotiation.

\section{Princeton and Saudi universities sign life sciences agreement}

PrINCETON University and the University of Riyadh in Saudi Arabia have signed an agreement under which each university will assist the other to build up a centre for training and research in the life sciences.

The Saudi Arabian university will donate $\$ 5$ million to Princeton, a substantial proportion of which will be used to modernise facilities in the university's Moffett Biological Laboratories, and the rest of which is likely to be used to support a number of new faculty posts in the biology department.

In return, Princeton has agreed the help the University of Riyadh to build up graduate and postdoctoral training and research facilities in the life sciences. This will be done both by advising on course curricula and the selection and training of personnel, and assisting with any necessary technical advice.

The agreement was signed in Riyadh last week by Princeton president Dr William G Bowen and the president of the University

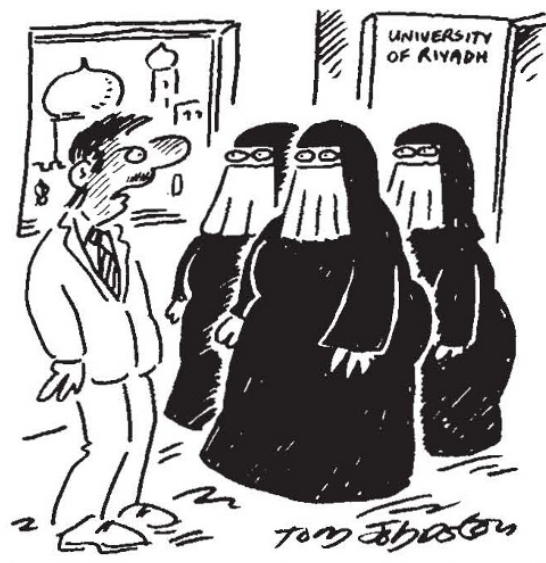

"No!! We won't be needing any cheer leaders!" of Riyadh, Dr Mansour Al Turki. It follows five years of negotiation between the two universities leading to what is believed to be the biggest single grant from an oil-producing state to an American university.

Dr Edward Cox, Chairman of Princeton's Biology Department, told Nature last week that the money would be used to provide additional support for fields of research, such as developmental biology, in which the university already has a strong research tradition.

Faculty members are currently debating the best way to use the new funds to support research salaries. "One view is that you could use the money for assistant professors, because it is the young people who are most in need of jobs", Dr Cox said. It might be possible to of fer a number of five or six year fellowships.

In return for the financing, the biology department will assist the University of Riyadh to set up an international life sciences centre for postgraduate students and postdoctoral fellows, most of whom now have to travel abroad to receive their research training.

Several previous attempts to establish cooperative agreements between US universities and Middle East countries have stumbled over the refusal of the latter to accept non-discrimination clauses leading to the fear that women, Jews and other minority groups might be excluded from participation.

The two universities have circumvented this problem by agreeing that scholars, technical experts and students will be proposed and received for exchanges "on the criterion of merit" rather than according to any other consideration.

David Dickson 